\title{
Resource Use Efficiency in Rice Production in Jere Local Government Area of Borno State, Nigeria.
}

\author{
B. A. Tijani ${ }^{1}$, M. Abubakar ${ }^{1}$, K. M. Benisheik ${ }^{2}$, , and A. B. Mustapha ${ }^{3}$ \\ ${ }^{1}$ Department of Agricultural Science and Technology, ${ }^{3}$ Department of Agricultural \\ Engineering, Ramat Polytechnic Maiduguri, Borno State, Nigeria. \\ ${ }^{2}$ Department of Agricultural Technology, College of Agriculture Gujiba, Yobe State, Nigeria.
}

\begin{abstract}
The study was carried-out on resource use efficiency in rice production in Jere Local Government Area of Borno State, Nigeria. Data were obtained using structured questionnaire. Five (5) wards were purposely selected out of the twelve (12) wards to reflect areas where rice is mainly grown. A total of 100 respondents were proportionately selected from the five (5) wards for the analysis. Descriptive statistics and production function were used as analytical tools. The result indicates that majority (87\%) were male, most (54\%) had farm size less than 2 hectares. Also, majority (60\%) indicated their major occupation as farming, most $(51 \%)$ had no formal education while, $(37 \%)$ had between 11-30 years of farming experience. The results of resource use efficiency in rice production showed that resources such as fertilizer, hired labour and rented land were under-utilized. The sum of elasticities of production indicates that there is increasing return to scale. It was recommended that farmers should be advised to increase use of rented land, improved rice seed, of fertilizer, hired and mechanized labours and chemicals. Farmers should also be encouraged to actively participate in adult education extension programme to acquire knowledge on how to use their farm resources efficiently in rice production.
\end{abstract}

Keywords: $\quad$ Resource, Efficiency, Rice, Borno State, Nigeria.

\section{INTRODUCTION}

Rice (Oriza sativa) is one of the staple food crops in many countries of the world especially in Africa, and it constitutes a major part of the human diet. In the past decades, the crop has seen a steady increase in demand and its growing importance is evident given it's place in the strategic food security planning policies (Nguyen and Tran, 2002). In 1996, Africa consumed a total of 11.6 million tonnes of milled rice per year of which 3.3 million tonnes were imported (i.e. 33.6\%). Nigeria ranked the highest as both producer and consumer of rice in the West Africa sub-region (Jones. 1995). Komolafe et. al. (1998) reported that rice is eaten by both man and animals, and also used in the manufacturing industries to produce starch.

The average annual rates of growth in rice production in Nigeria hove declined in recent years (Okuneye. 2001; Akinbola, 2002). The major sources of decline in production is attributed to: fluctuation of water table; and attendant danger of flooding; inadequate water supply at the end of dry season; high cost of water fitting device; lack of improved seed and high cost of labour (Goni et al., 2007).

The Federal Ministry of Agriculture (FMA) (1993) estimated that the annual supply of food crops (including rice) world have increased at an average annual rate of $5.9 \%$ to meet food demand, and reduce food importation significantly. Several studies have shown that aggregate rice production in Nigeria has been growing at an about $2.5 \%$ per annum in recent years (Olayemi, 1998; Akinbola, 2002; Amaza and Olayemi, 2002). But the annual rate of population growth has been high able to attain self-sufficiency in rice production despite increasing hectares put into production annually (CBN, 2002).

The low agricultural productivity in Nigeria is revealed by actual yields of major crops such 
as rice compared with potential yield (FMA, 1993). The implication is that there is scope for additional increase of output from existing hectares of rice, if resources are properly harnessed and efficiently allocated (Goni et. al., 2007). It is against this background that this study intend to determine efficiency of resource use in rice production in Jere Local Government Area of Borno State, Nigeria to bridge the gap in existing knowledge on resource use efficiency research in the study area. The choice of Jere Local Government Area of Borno State is premised on the fact that it is one of the largest rice producing areas in the state. The economic importance of rice and it's significance in the economic development of the nation -therefore, call for a sustain research work on all aspect of rice production.

The study attempts to provide answers to the following questions:

What are the socio-economic characteristics of rice farmers?

Are resources efficiently utilized in rice production?

The main objectives of the study was to determine the efficiency of resource use in rice production in Jere local government Area of Borno State, Nigeria. The specific objectives are to:

examine the socio-economic characteristics of rice farmers;

determine the efficiency of resource use in rice production.

\section{METHODOLOGY}

The study area is Jere Local Government Area, one of the twenty-seven Local Government Areas of Borno State. The Local Government Area was carved out of Maiduguri Metropolitan Council (M.M.C) in 1996 (BSG, 2007). It lies within latitudes $11^{\circ} 40^{1}$ and $12^{0} 05 \mathrm{~N}$ and longitudes $13^{\circ} 50^{1}$ and $12^{0} 20^{1} \mathrm{E}$, it occupies a total landmass of 160 square kilometer (MLS, 2008). Within the state, it shares boundaries with Mafa Local Government Area to the east, Maiduguri Metropolitan Council to the north and Konduga Local Government Area to the south. The climate of the area is characterized by dry and hot seasons, minimum temperature ranging from $15-20^{\circ} \mathrm{C}$, while the maximum temperature ranges from $37-45^{\circ} \mathrm{C}$. The annual rainfall ranges from $500 \mathrm{~mm}$ to $700 \mathrm{~mm}$ per annum (NMA, 2008). The rainy season is usually from May to October with low relative humidity and short wet seasons. The topography is generally low land plain, and the soil is generally sandy with short grasses and thorny shrubs. Jere Local Government Area has a projected population of 211,204 persons with annual growth rate of $2.8 \%$ (NPC, 2006). Majority of the inhabitants are farmers, traders and civil servants. The major ethnic groups are Kanuri and Shuwa-Arab. Others includes Hausa, Bura and Fulani and many immigrant settlers from within and outside Nigeria (B0SADP, 2008).

Five (5) wards were purposively selected out of the twelve (12) wards in the area. These are the areas where rice crop is predominantly grown. These include, Zabbarmari, Gongolon, Alau, Lawanti and Dusuman wards. Multistage sampling procedure was used to select two (2) villages randomly in each ward. Ten (10) rice farmers were randomly selected from each village making a total of one hundred (100) respondents for the study area. Data for the study were obtained from both primary and secondary sources. The primary data was obtained with the aid of a structured questionnaire and personal interview was also conducted for farmers who cannot read and write; and the results of the interview were interpreted in the questionnaire. While the secondary sources of information includes textbooks, journals, past project, internet, etc. Data were collected on socio-economic variables such as gender, farming experience, age, educational level, household size, farm size and income level of respondents. Also data were obtained on costs and returns and problem associated with rice production in the study area. The analytical tools employed for this study include, descriptive statistics and production function.

The descriptive statistics that were used include percentage and frequency. These were used to analyze the socio-economic characteristics of the respondents to achieve objective (i). Production function model was 
used to determine the physical relationship between inputs and output obtained in rice production; and the coefficient of the double$\log$ function (elasticity) was obtained to estimate efficiency of resource-use to achieve objective (ii). The implicit form of the model is expressed as follows:

$\mathrm{Y}=\mathrm{F}\left(\mathrm{X}_{1}, \mathrm{X}_{2}, \mathrm{X}_{3}, \mathrm{X}_{4}, \mathrm{X}_{5}, \mathrm{X}_{6}, \mathrm{X}_{7}, \mathrm{e}\right)$.

Where:

$\mathrm{Y}=$ Output of rice $(\mathrm{kg})$

Different functional forms were tried for the analysis. This includes: linear, semi-log, double-log and exponential functions out of which the double-log function was chosen and used to estimate the technical efficiency of resource-use in rice production. The choice of the best functional form (lead equation) was based on both statistical and econometric criteria (T-test, F-statistics, $\mathrm{R}^{2}$ ) and a priori expectation of the signs of the coefficients. It was expected a priori that the coefficients of $\mathrm{X}_{1}, \mathrm{X}_{3}, \mathrm{X}_{4}$ and $\mathrm{X}_{6}$ would be positive, while those of $\mathrm{X}_{2}, \mathrm{X}_{5}$ and $\mathrm{X}_{7}$ would be negative. Also, farmers resource use in rice production was expected to be efficiently utilized. The following ratio was used to estimate the relative efficiency of resource use (r).

\section{$r=\quad$ MVP \\ MFC}

Where:

MFC $=$ Cost of one unit of a particular resource

MVP = Value added to rice output due to the use of an additional unit of input calculated by multiplying the MPP by the price of output i.e. $\mathrm{MPP}_{\mathrm{xi}} \mathrm{X} \mathrm{P}_{0}$.

If

$\mathrm{r}=1$ Resource is efficiently utilized

$r=>1$ Resource is under utilized

$\mathrm{r}=<1$ Resource is over-utilized.
$\mathrm{X}_{1}=$ Quantity of seed $(\mathrm{kg})$

$\mathrm{X}_{2}=$ Farm size (ha)

$\mathrm{X}_{3}=$ Herbicide/insecticide used (litres)

$\mathrm{X}_{4}=$ Hired labour (no man days)

$\mathrm{X}_{5}=$ Family labour (no man days)

$\mathrm{X}_{6}=$ Fertilizer used $(\mathrm{kg})$

$\mathrm{X}_{7}=$ Mechanize labour ( $)$

$\mathrm{e}=$ Error term .

Economic optimum take place where MVP = MFC. If $r$ is not equal to (1), it suggests that resource is not efficiently utilized. Adjustments could therefore be made in the quantity of input used and costs in the production process to restore $r=1$. The elasticity of production which is the percentage change in output as a ratio of a percentage change in input use to calculate the rate of return to scale which is a measure of a firm's success in producing maximum output from a set of inputs (Coeilli and Battesse, 1996).

$\mathrm{EP}=\mathrm{MPP} / \mathrm{APP}$

Where:

$\mathrm{EP}=$ Elasticity of production

MPP $=$ Marginal physical product

APP $=$ Average Physical product

If

$\Sigma E P=1$ : Constant return to scale

$\Sigma \mathrm{EP}=<1$ : Decreasing return to scale

$\Sigma \mathrm{EP}=>1$ : Increasing return to scale.

\section{RESULTS AND DISCUSSION}

Socio-economic Characteristic of Respondents

The socio-economic characteristics of respondents examined include: gender, age, education level, farm size, major occupation, farming experience and annual income. The findings are presented in Table 1. 
Table 1: Socio-economic Characteristics of Respondents

\begin{tabular}{|c|c|c|}
\hline Socio-economic Variable & Frequency & Percentage \\
\hline \multicolumn{3}{|l|}{ Gender: } \\
\hline Male & 87 & 87 \\
\hline Female & 13 & 13 \\
\hline Total & 100 & 100 \\
\hline \multicolumn{3}{|l|}{ Age (Years): } \\
\hline Les than 30 & 18 & 18 \\
\hline $31-40$ & 34 & 34 \\
\hline $41-50$ & 33 & 33 \\
\hline 50 and above & 15 & 15 \\
\hline Total & 100 & 100 \\
\hline \multicolumn{3}{|l|}{ Educational Level (Years): } \\
\hline No Formal Education & 51 & 51 \\
\hline Tertiary & 23 & 23 \\
\hline Secondary & 16 & 16 \\
\hline Primary & 10 & 10 \\
\hline Total & 100 & 100 \\
\hline \multicolumn{3}{|l|}{ Farm Size (ha): } \\
\hline Les than 2 & 54 & 54 \\
\hline $2.0-4.0$ & 31 & 31 \\
\hline 4 and above & 15 & 15 \\
\hline Total & 100 & 100 \\
\hline \multicolumn{3}{|l|}{ Occupation: } \\
\hline Farming & 60 & 60 \\
\hline Business & 18 & 18 \\
\hline Fishing & 14 & 14 \\
\hline Civil Servant & 8 & 8 \\
\hline Total & 100 & 100 \\
\hline \multicolumn{3}{|c|}{ Farming Experience (Years): } \\
\hline Less than 10 & 13 & 13 \\
\hline $11-30$ & 26 & 26 \\
\hline $31-50$ & 39 & 39 \\
\hline 50 and above & 22 & 22 \\
\hline Total & 100 & 100 \\
\hline \multicolumn{3}{|l|}{ Annual farm Income (N): } \\
\hline$<\$ 50,000$ & 13 & 13 \\
\hline$\$ 51,000-\$ 100,000$ & 31 & 31 \\
\hline$\$ 101,000-\$ 200,000$ & 35 & 35 \\
\hline$\$ 201,000$ and above & 21 & 21 \\
\hline Total & 100 & 100 \\
\hline
\end{tabular}

Source: $\quad$ Field Survey, 2008.

Analysis of the finding in Table 1 shows that majority $(87 \%)$ of the respondents were male, while only $13 \%$ were female. This indicates that majority of the rice farmers in the study area were male. This is probably because male farmers have great responsibility in their families as heads. Thus, engage in rice farming to supply food and other household basic 
needs. This supports the findings of Tijani (2007) that majority of the farmers $(77.5 \%)$, $(80.0 \%),(75.5 \%)$ engaged in sorghum, millet and groundnut production, respectively in Borno State, Nigeria, were male, while $22.5 \%$, $20.0 \%$ and $27.5 \%$ were female. Thus, more males engage in agricultural activities than females. Gender is a significant factor in agriculture because of it's vital role in determining the farmers agricultural activities. In the northern Nigeria, males engage more in agricultural activities than female due to the drudgery involved in agriculture. Besides, the purdah system (seclusion of women) limits women's active participation in agriculture.

The result also indicates that $18 \%$ of the respondents fell within the age group of less than 30 years, $(31 \%)$ were within the age group of $31-40$ years, $33 \%$ were within the age group of $41-50$ years, while $15 \%$ were within the age group of 50 years and above. The finding shows that most of the respondents were in their active and productive age group. The reason is obvious, the age of a farmer has an effect on the type of agricultural activities he may engage in. For instance, in family labour, younger farmers spend much time on the farm and they mostly embark on more strenuous farm operations than older farmers and children. This conformed with the findings of Kolo (2004) that most farmers between 31 to 50 years of age in Niger State, Nigeria are in their active age which enabled them to perform actively in strenuous farm activities and they constitute $82.30 \%$ of the farming population.

The level of education attained by farmers to a large extent determine the farmers level of adoption of new innovation without difficulties which inturn increase their farm output, and subsequently the profit obtain by the farmers (11TA, 2002). The result of the analysis indicates that $51 \%$ of the respondents had no formal education, $23 \%$ had tertiary education, $16 \%$ had secondary education, while $10 \%$ had primary education. This reveals that most of the respondents did not undertake any form of formal education.

The finding shows that majority $54 \%$ of the respondents had farm size less than 2 hectares, $31 \%$ had between $2.0-4.0$ hectares, while only
$15 \%$ had 4 hectares and above. This indicates that majority of the respondents had less than 2 hectares of farm size. From result of the findings, majority of the farmers can therefore, be categorized as small-scale farmers. This is inline with the assertion by F.A.O, (1998) that most of the farmers in Nigeria were small-scale farmers who cultivate less than 5 hectares of land. Similarly, Tijjani (2007) reported that majority $(72.0 \%)$ of the farmers in Borno state, Nigeria are small-scale farmers who had farm sizes between 3-4 hectares.

The results of the analysis also indicates that $18 \%$ of the respondents were engaged in other businesses, $14 \%$ were civil servants and $8 \%$ were fishermen, while majority $60 \%$ indicated their major occupation as farming. This shows that majority of the respondents are farmers in the study area.

The result also indicates that $13 \%$ of the respondents had less than 10 years of farming experience, $26 \%$ had between 11-30 years, $39 \%$ had between $31-50$ years, while $22 \%$ had 50 years and above. The result shows that most of the farmers had between 31-50 years experience in farming which constitutes the highest proportion of the population. The higher the number of years spent in farming by a farmer, the more he becomes aware of new production techniques (Amaza and Olayemi, 2002).

The finding also indicates that $13 \%$ of the respondents had less than $\$ 50,000$ annual income, $31 \%$ had between $\$ 51,000$ $\$ 100,000,35 \%$ had between $\$ 101,000$ $\$ 200,00$, while $21 \%$ had $\$ 200,00$ and above annual income in farming. This supports the finding by Tijani (2007) and Abubakar (2004) that annual income of a farmer determines his ability to purchase improved farm inputs such as fertilizer, hired labour improved seed, chemicals and other improved technologies, which may bring about increase in productivity and subsequently leads to higher farm income. Thus, the higher the annual income of a farmer, the greater the scale of agricultural production he can undertake and the higher the profit in farming.

Resource Use Efficiency in Rice Production: Resource use efficiency of farmers was 
Tijani $t$ al., Resource Use Efficiency in Rice Production in Jere Local Government Area of Borno State, Nigeria.

estimated using the double-log functional farm's coefficients (elaticities) of the various farm inputs used in rice production in the study area. The findings are presented in Table 2.

Table 2: $\quad$ Resource Use Efficiency, Elasticity of Production and Scale in Rice Production

\begin{tabular}{lllllll}
\hline Resources & MVP & MFC & $\begin{array}{l}\text { MVP } \\
\text { Seed }\left(X_{1}\right)\end{array}$ & $\begin{array}{l}\text { Elasticity of } \\
\text { production }\end{array}$ & $\begin{array}{l}\text { Efficiency } \\
\text { Gap }\end{array}$ & $\begin{array}{l}\text { Divergence } \\
\%\end{array}$ \\
Rented land $\left(X_{2}\right)$ & 360.5 & 300 & 1.20 & 3.219 & 60.5 & 16.79 \\
Chemical $\left(X_{3}\right)$ & 4650.9 & 400 & 1.16 & 0.003 & 650.9 & 13.99 \\
Hired labour $\left(X_{4}\right)$ & 4900.5 & 4500 & 1.09 & 0.310 & 400.5 & 8.17 \\
Family labour $\left(X_{5}\right)$ & 2200.5 & 2000 & 1.10 & 0.001 & 200.5 & 9.11 \\
Fertilized used $\left(X_{6}\right)$ & 1250.9 & 1200 & 1.04 & 0.195 & 50.9 & 4.06 \\
Mechanized $\left(X_{7}\right)$ & 5650.8 & 5000 & 1.13 & 0.160 & 50.8 & 11.51 \\
& 3250.10 & 3000 & 1.08 & 0.120 & 250.1 & 7.69
\end{tabular}

Return to Scale (Total)

3.378

Source: Computed from Field Survey Data, 2008.

The double-log functional forms' coefficients were used to estimate the efficiency of resource use, since it is the elasticity of production. Analysis of the finding in Table 2 indicates that the total sum of the elasticities of production was 3.378. This implies that one percent increase in the quantity of the variables will result in 3.378 percent increase in rice output. This indicates an increasing return to scale which is the characteristic of stage 1 of the production function. This further suggests that the resources taken together are at present being under utilized and so farmers can have more returns by increasing the quantities of these resources. Measures of technical efficiency of resources use such as marginal value product (MVP) and marginal factor cost (MFC) were derived.

The result reveals that the ratios of the MVP to the MFC were greater than unity (1) for all the inputs. This implies that inputs such as seed, rented land, chemical, hired labour, family labour, fertilizer and mechanized labour were under-utilized. This means that rice output was likely to increase and hence revenue, if more of such inputs (seed, rented land, chemical, hired labour and so on) had been efficiently utilized. The adjustment in the MVPs for optimal resources use (\% divergence) in Table 2 indicates that for optimum allocation of resources more than $13.99 \%$ increase in rented land was required while, approximately $4.06 \%$ increase in family labour was needed. Similarly, over 16.78 increases in seed was required and approximately $11.51 \%$ increase in fertilizer for optimal use in rice production. It should be noted that the MVPs of seed, rented land, chemicals, hired labour, family labour and mechanized labour were not negative indicating that rice farmers still use these resources within the 
economically rational range even though they were not optimally used.

Conclusion and Recommendation: The study reveals that rice farmers were technically inefficient in the use of farm resources. The inefficiency of the farmers may be directly or indirectly linked to the high cost of fertilizer, rented land, seed, hired and mechanized labour. Improvement in the efficiency amongst the farmers is the responsibility of the individual farmers, government and research institutions. The provision of improved rural infrastructures and enabling policies such as making available all agricultural inputs required at the right time and at affordable prices among others are also required in order to enhance efficiency. Based on the findings

\section{REFERENCES}

Abubakar, I. (2004). Resource Use Efficiency in Yam Production in Northern Part of Taraba State, Nigeria. Unpublished M.Sc Dissertation, Department of Agricultural Economics and Extension, University of Maiduguri, Nigeria.

Akinbola, G. E. (2002). Poverty Reduction Through the Crop Sub-Sector in Nigeria. A Regional Perspective Poverty Reduction and the Nigeria Agricultural Sector. ElShaddai Global Ventures Ltd. Pp. 39 - 52.

Amaza, P. S. and Olayemi, J. K. (2002). "Analysis of Technical Efficiency in Food Crop Production in Gombe State", Nigeria Journal of Applied Economics Letters. Vol. 9 Pp. $51-54$.

Borno State Agricultural Development Programme (BOSADP) (2008). Office Memo File.

Borno State Government (BSG) (2007). Official Diary of Ministry of Information, Home Affairs, Maiduguri, Nigeria. Pp. 5- 7.

Central Bank of Nigeria (CBN) (2002). Statistical Year Bulletin, Vol. 2 No. 2. Pp. $55-57$. of the study, the following recommendations were made:

i) Extension agents in the state should be properly trained and provided with all the necessary technological packages required to teach and guide farmers on improved agricultural technologies to reduce cost of production.

ii) Non-governmental organizations and research institutes in collaboration with the farmers cooperative groups should provide improved agricultural technologies such as improved seeds, fertilizer etc at affordable rate to the farmers.

Coelli, J. F. and Battese, G. E. (1996). "Model for Technical Inefficiency Effect in a Stochastic Frontier Production Function and the Efficiencies of India Farm Using Panel Data from Krizatis Village Level Studies". Journal of Quantitative Economics Vol. 5 Pp. 185 - 208.

Food and Agriculture Organization (FAO) (1998). Rice Production in Africa: Current Situation and Issues. By Agriculture Department Group, FAO Regional Offices for Africa, at the Nineteenth Session of the International Rice Commission, Cairo, 7-9 Sept. 1998.

Federal Ministry of Agriculture (FMA) (1993) Official Bulletin. In: Amaza, P. S. and Olayemi, J. K. (eds). Analysis of Technical Efficiency in Food Crop Production in Gombe State, Nigeria. Journal of Applied Economics Letter Vol. 9: Pp. 51 - 54.

Goni, M., Mohammed, S. and Baba, B. A. (2007). Analysis of Resource Use Efficiency in Rice Production in the Lake Chad Area of Borno State, Nigeria. Journal of Sustainable Development in 
Agriculture and Environment, Vol. 3 Pp. $31-37$.

International Institute of Tropical Agriculture (IITA) (2000). IITA Annual Report, IITA Ibadan, Nigeria. Pp. $19-30$.

Jones, M. P. (1995). The Rice Plant and its Environment. West African Rice Development Association Training Guide Vol. 2 Pp. $1-16$.

Kolo, M. G. M. (2004). Herbicides Utilization by Farmers in Niger State, Nigeria. Nigerian Journal of Weed Science, Vol. 17: Pp. 21 28.

Komalafe, J. F., Enyeke, J. A. and Osagie, B. F. (1998). Nigeria Small Farmers: Problem and Prospects in Integrated Rural Development.

Ministry of Land and Survey (MLS) (2008). Maiduguri, Borno State, Nigeria Office Memo File Vol. 4 Pp. 55-58.

Nguyen, V. N. and Tran, D. V. (2002). Issues and Challenges of Sustainable Rice Production for Food Security in SubSaharan Africa Paper Presented at the FAO Sub-Regional Workshop Programme in the ECOWAS Sub-Regional Office for Africa, Ghana.

Nigerian Metrological Agency (NMA) (2008). Annual Report. Office Memo File.

National Population Commission (NPC) (2006). Population Census Data Borno State, Nigeria Federal Republic of Nigeria
Official Gazette, National and State Provisional Totals Census. Printed and Published in 2007 by the Federal Government Printer, Lagos, Nigeria. 94 (21): $175-198$.

Okuneye, P. A. (2001). Rising Cost of Food Rice and Security in Nigeria and its Implication for Poverty Reduction. Central Bank of Nigeria Economic and Financial Review Vol. 39 December 2001, No. 14 pp. 88 110.

Oyebanji, O. O. and Ibanaga, I. J. (1994). Weed Management Technology Transfer in Nigeria: Problem and Needed Strategies for Adaptable Research and Extension. Symposium Paper Presented at the $21^{\text {st }}$ Annual Conference of the Weed Science Society of Nigeria held at Ilorin, Kwara State, $4^{\text {th }}$ to $8^{\text {th }}$ December. Nigeria Journal of Weed Science, Vol. 7. Pp. 25- 33.

Olayemi, J. K. (1998). Food Security in Nigeria. Research Report No. 2, Development Policy Centre Ibadan, Nigeria Vol. 2 Pp. 1- 85.

Tijani, B. A. (2007). Comparative Economic Analysis of Weed Control Methods for Selected Crops in Marte Local Government Area of Borno State, Nigeria. Unpublished M.Sc Dissertation, Department of Agricultural Economics and Extension, University of Maiduguri, Nigeria. Pp. 93. 